\title{
国際ヒト エピゲノム コンソーシアム
}

\section{Time for the epigenome}

2010 年 2 月 4 日号 Vol. 463 (587)

自然界の驚異の 1 つ、それが、遺伝子が発現する際になされている複雑な「調節」の機構だ。 この気の遠くなるような課題の解明に向けて、国際プロジェクトが始まった。

それは 2004 年のことだった。ハーバー ド大学（米国マサチューセッツ州ボスト ン）の腫瘍学者 Ronald DePinho は、急 成長を始めた「がんエピジェネティクス」 の学会に出席して何気なく質問した。「こ れから 5 年後、この分野はどれくらい発 展して欲しいと思いますか」。この質問 が、その後、大きな波紋を広げていった。

ゲノムの塩基配列は、同じ生物種内 でも異なる生物種間でも、あまりにも 似すぎていて「生物がもつ多様性」を 説明することはできない。この事実は、 2004 年の時点で、既に大規模ゲノム計 画によって明らかにされていた。いった い、類似性の高い遺伝コードは、どん な仕組みによって、異なる時点、環境 条件、細胞において、それぞれ一意的 に発現するのか。少なくとも、その謎 の多くは「エピジェネティクス」によっ て説明できる可能性があると考えられ た。エピジェネティクスとは、DNA と その関連タンパク質の化学修飾が原因 で生じる「遺伝子発現の変化」のこと である。

エピジエネティクス研究者は、爆発的 に増加する新データに圧倒されていた。 しかし何人かが、考えをまとめて行動 に出た。翌 2005 年、米国癌学会の後援 によるワークショップを開催したのだ。 参加者たちは「ゲノム全域でのエピジエ ネティック修飾のマップ」、すなわち 「エピゲノム」というコンセプトに焦点 をしぼった。そして、それを解明する プロジェクトの青写真を作成した。対 象はがんエピジェネティクスの範囲を
超え、また、すべての生物学関連分野 を巻き込む国際的活動に発展すると想 定された。そもそも遺伝子の発現調節 という仕組みは、すべての生物や細胞 に共通する基本原理であり、生物学者 は、最初から共通言語で議論する必要 があつたからだ。

この青写真が練り上げられて国際ヒ トエピゲノムコンソーシアム (IHEC) となり、2010 年 1 月に始動した (Nature 2010 年 2 月 4 日号 596 ページ参照)。 6 年前のDePinho の質問に対して、今 ならどんな答えが返ってくるだろうか。 おそらく、「数年以内に、数百点の信頼 性の高い標準（参照）エピゲノムを、 パソコン上で自由に利用できるように なる」であろう。

エピジェネティクスは不確実性の多 い複雑な分野であるため、エピゲノム の解明をめざす IHEC のような巨大プロ ジェクトが、このタイミングで新たに始 動することに二の足を踏む人がいるか もしれない。しかし、この複雑な分野に 一定の道筋をつける、という目標を考え れば、ちょうどよい夕イミングでのス タートだといえる。「時機を逸している」 との批判は、ある面では当たっている。 米国では、国立衛生研究所 (NIH) が既 に複数の標準エピゲノム解析センター を設置し、欧州委員会もまもなく同様の 施設を開設する計画になっているから だ。しかし、ビッグサイエンス対スモー ルサイエンスという陳腐な論争は、再燃 させるべきではない。スモールサイエン スは確実に続行され、IHEC の標準エピ
ゲノムにとって、多くの貢献が期待でき るからだ。むしろ、資金提供機関、でき れば産業界も、この十分に価值のある研 究に資金を提供すべきである。

IHEC の熱心な支持者は、これを「生 物学版のハドロン衝突型加速器 (LHC)」 とよぶ。ヨーロッパ素粒子物理学研究 所 (CERN) の国際プロジェクト LHC は、宇宙を支配する物理学の標準モデ ルが正しければ存在するはずの、最も 基本的な素粒子の発見をめざしている。 もし生物学者が、これに相当する「生 物の多様性の根拠となる生物学的コー ドの標準モデル」を考えているのであ れば、遺伝コード自体は、ほんの一部 にすぎない。残りのかなりの部分に寄 与しているのが、エピジェネティクス である可能性は高い。

機械設備だけを比較すれば、IHEC は LHC に大きく見劣りする。費用の点 でも LHC ほどの規模はない。しかし、 IHECの科学的ビジョンには、LHCと 同じくらいの説得力がある。また、エピ ジェネティックなコードは、遺伝コード よりも桁違いに複雑になると予想され、 データの解読には、LHC 並みの情報解 析が必要となる可能性もある。そして何 より、IHEC による研究が進めば、健康 と病気、特に治療の困難ながんのような 病気に関する情報が得られるはずだ。以 上のすべての理由から、ヒトエピゲノム プロジェクトは、LHC と同様、取り組 む時機が到来した課題といえる。

(翻訳 : 菊川要) 